\title{
The YMCA and the Origins of American Freshman Orientation Programs
}

\author{
Dorothy E. Finnegan \& Nathan F. Alleman
}

\begin{abstract}
Scholarship on the history of student services and in particular freshman orientation programs typically begins with the administrative interventions of the mid-1920s. However, freshman orientation services and activities did not arise from administrative or faculty initiatives. As early as the late 1870s and motivated to ensure the welfare of their own student organization, members of campus-based Young Men's Christian Associations recognized needs of incoming students and gradually developed college entry programs, resources, and strategies in response. These interventions were designed to ameliorate and influence the otherwise difficult transition process into collegiate life. This research illustrates the lineage of freshman socialization efforts, which were initiated by the Student Associations found on most campuses across the United States.
\end{abstract}

RÉSUMÉ

L'histoire des services aux étudiants et, en particulier, les études portant sur les programmes d'orientation destinés aux nouveaux étudiants, coïncident manifestement avec les interventions administratives du milieu des années 1920. Cependant, les services et les activités pour les étudiants de première année n'ont pas été initiés par l'administration ou les facultés. Ce sont plutôt des membres universitaires des Young Men's Christian Associations (YMCA) soucieux du bien-être dans leur propre organisme et des besoins des nouveaux étudiants qui ont développé, à partir des années 1870, des programmes, mis en place des ressources et des stratégies d'orientation. Ces interventions étaient conçues pour améliorer et faciliter l'intégration à la vie étudiante. Cette étude retrace l'histoire de ces efforts entrepris par les associations étudiantes que l'on retrouve sur la plupart des campus aux États-Unis.

In September of 1923, the University of Maine hosted a week-long pre-term event for new students, the first institutionally-sponsored and intensive event of its kind. Freshman Week, as it was called by the program's creator, Clarence Cook Little, Maine's young, newly-installed president, was crafted to address "the transition period from school to college... with the arrival of the freshman on the college campus. Like a row boat thrown blindly from a wharf he is likely to be completely swamped by the tremendous confusion of his environment." ${ }^{1}$ Freshman Week served dual 
purposes, seguing students from high school to college and permitting faculty and staff to assess the aptitudes of their new recruits. By the late 1920s Freshman Week as a concept had spread to more than a dozen institutions, and by the early 1930s, was a common feature of many collegiate fall terms across the nation. ${ }^{2}$ For his part, years later Dr. Little indicated that the idea for Freshman Week resulted from a

Study of undergraduate records [that] showed that there was a high degree of maladjustment and a large number of "drop-outs" soon after the students came to Orono. In this situation, homesickness, loneliness, and lack of understanding of what a college was and the sage use of its faculties and opportunities loomed up as all-important factors. ${ }^{3}$

However, even before President Little had begun to conceptualize his orientation program, a campus student religious group at the University of Maine was already engaged in a set of services and activities designed to accomplish many of the nonacademic socialization goals that the administrative pre-term event posed. Across the country, the campus-based groups of the Young Men's Christian Association (YMCA or Y) in fact had been creating and sustaining orientation functions by degree for some 40 years prior to Little's innovation. This paper explores the cumulative and sophisticated range of freshman socialization and orientation activities conducted by YMCA student members on campuses across the nation from 1878 through the 1930s.

Although at first the motivation behind the Y's efforts was evangelical propagation and organizational survival, the student-initiated and -led programs nevertheless represented the primary and generally the only orientation opportunities for college students at hundreds of institutions prior to the 1920s. Acknowledging the efforts of the YMCA as the architects of orientation activities modifies the accepted narrative of the administrative authors of the 1920s and 1930s. By describing the YMCA-initiated new students' services and programs that developed between 1878 and the 1920s, we not only demonstrate the strengths and liabilities of adaptive, student-led services operating as the de facto orientation system for freshman students, but also highlight the diverse and often overlooked antecedents of the student affairs profession.

Scholars recently have been filling in the gaps in the history of student affairs. Work on the evolution of the roles of deans of women and eventually of men has extended our understanding of the development of personnel services; thus the story of the subsequent institutionalization of student affairs departments has become more robust. ${ }^{4}$ The customary explanation of the development of the student personnel movement begins with the installation of a small three-person office devoted to testing and counseling at Northwestern University in 1922, leading to the eventual adoption of the Personnel Point of View statement in 1937. 5 Scholars have also been exploring the development of student life on campus. From Helen Horowitz's descriptions of student sub-cultures and Paula Fass' analysis of students during the Roaring '20s to the exploration of the development of student-initiated and -organized athletics, our knowledge of student life on campus has increased in texture. ${ }^{6}$ Ronald Smith and 
John Thelin among others have documented the rise of competitive intercollegiate athletics and its fall into disarray resulting in the faculty and administrators assuming control. ${ }^{7}$ Absent though is an adequate explanation of the actual shift from the limited administrative and faculty intervention in student life after the Civil War to other specific standardized and institutionalized practices of student affairs.

The increase in student enrollments and the participation rate in colleges are often cited as primary reasons for the remarkable administrative specialization following World War I. Yet, the magnitude of heterogeneity within the enlarging collegiate population is often disregarded. Students from diverse socio-economic and ethnic backgrounds entered college prior to but especially after the war in unprecedented numbers. Many new students began their collegiate life without benefit of familial socialization and the traditional educational coaching from private preparatory schools, which had long supplied certain institutions. Significantly also, the new populations suffered high attrition rates due to a lack of finances rather than scholastic problems. ${ }^{8}$

Reminiscent of presidential $19^{\text {th }}$ century moral philosophy lectures, a few presidents, a dean or two, and the occasional faculty member published speeches or lectures given to freshman in the first years of the new century. ${ }^{9}$ Yet with the diverse institutional changes that were occurring, "how to turn the bewildered freshman as speedily as possible into a college man [became] a problem which the growth of numbers and the variety of the curriculum [made] increasingly difficult." ${ }^{10}$ However, the imperative to orient new students beyond the provision of avuncular advice was not addressed intentionally until well into the post-war enrollment boom with Little's Freshman Week. During the later years of the 1920s and into the 1930s, a considerable number of scholars described the new innovation of freshman orientation and others took note of the recent advances in these institutional activities. ${ }^{11}$ And by the mid-1930s, scholars had begun to actually study orientation practices in place. ${ }^{12}$

However, the scholarship on orientation continues to focus on the nature of current programs and is devoid of its history. ${ }^{13}$ Without acknowledging the student initiatives, even the most insightful historical work pinpoints the rise of freshman orientation programs in the mid-1920s as the administrative intervention that filled the void when faculty shifted their attention to scholarship. ${ }^{14}$ Institutionalized freshman orientation did not emerge in the 1920s sans progenitor. Rather, specific students identified the needs of their peers and acted upon their intuition much earlier as a latent orientation function of their manifest religious intent. This research illustrates the lineage of freshman socialization efforts, which were initiated by students themselves.

\section{The Roots of Freshman Orientation}

In the last quarter of the $19^{\text {th }}$ century, college attendance was still not a common activity for most young Americans and yet colleges continued to spring up across the established nation. In 1879, 811 colleges and universities enrolled 115,850 students, two-thirds of whom were men. Although the average per institution calculates to 143 students, established eastern colleges attracted more students than most 
newly-established ones in the mid-western and southern states. Having recently expanded to include graduate degrees, Harvard enrolled 1,175 male students by 1875; its undergraduate population numbered 706, of whom 270 were freshmen. That same year, Cornell, only ten years old, enrolled 542 undergraduates. ${ }^{15}$

Unless they were graduated from a preparatory school with which their intended college held a compact, prospective students gained entrance into most colleges through institutional examinations held just prior to the start of the fall term. As long as applicants numbered in the dozens or hundreds, this method worked well; students who were not prepared could be funneled into the preparatory department rather than be turned away. However, after the turn of the century, student enrollments increased yearly. By 1900, for example, Cornell's undergraduate enrollment stood at 2,316 with another 205 graduate students sharing the campus. Twenty years later, the combined enrollment numbered 5,668 including 440 graduate students. Gradually, the public universities in the mid-west also expanded and after World War I at an even higher rate. The increased popularity of college attendance after the war made institutional examination cumbersome; a more standardized process had to come to light. Thus, by the early 1920s, many colleges accepted high school graduation as a sign of adequate preparation for college, but continued to utilize institutional entrance examinations for students coming with questionable training. ${ }^{16}$

During the last years of the $19^{\text {th }}$ century and the first decades of the new century, these pre-term entrance examination days afforded first-year students only a small window of time to acclimate to their new surroundings, to find room and board so often not provided by the colleges, and possibly to secure employment to help defray their expenses. However, beyond the examinations, catalogues, and registration processes, colleges offered no institutionalized help to new students in their attempt to adjust to their new environment. ${ }^{17}$ Into this void of explicit orientation services stepped the campus YMCAs.

\section{The YMCA College Movement}

Oblivious to each other, students at the Universities of Virginia and Michigan established their own campus YMCAs in 1858. This student grass-roots religious organizational movement swept the nation during the post-Civil War period and through Progressive Era. ${ }^{18}$ In the early days, Y members gathered on their campuses in studentinitiated Bible-study classes and then attempted to strengthen the local Christian community through deputations to townspeople and rural neighbors. Rather than remaining isolated on their individual campuses, they corresponded with members on other campuses through a national newsletter, The College Bulletin, ${ }^{19}$ participated in state-based college YMCA meetings, and as of the mid-1880s sent representatives to ten-day regional summer camps to receive religious and organizational instruction from national YMCA officers, who were based in New York City. ${ }^{20}$ Far from a fleeting enthusiasm, The University of Michigan Y's Students' Hand-Book, 1899-1900 boasted the existence of 595 student associations across the nation; among these were 269 in colleges and universities and the rest spread through specialized institutions 
(law, medicine, military, etc.). The number included $48 \mathrm{HBCU}$ and five Indian student associations. By 1912, the Y claimed 69,296 members, or just under one-third of the male college-going population. A total of 772 YMCAs operated at $80 \%$ of college campuses, or slightly more than 1,000 American public and private colleges, normal schools, and seminary campuses, including 100 historically Black colleges. ${ }^{21}$

\section{YMCA Freshmen Orientation Services ${ }^{22}$}

By 1910, the campus YMCAs on both large and small institutions provided extensive orientation services designed to address genuine needs that most students felt as they began their collegiate careers. Beginning in 1878, the number of services gradually developed as the associations grew in membership and organizational knowledge. Student association members provided incoming freshmen with logistical and academic information, housing and employment opportunities, introductions to faculty and upperclassmen, and eventually student leadership programs as part of their orientation repertoire. ${ }^{23}$ The first point of contact between the $\mathrm{Y}$ associations and new students was the student handbook.

\section{The YMCA Student Handbook}

As early as 1883 , at least four student handbooks had been compiled and produced by campus YMCAs: University of Virginia, Northwestern University, Otterbein University, and Hillsdale College; the Ys at Ohio State and the University of Illinois joined the ranks the following year. The concept of producing a handbook especially for freshman spread rapidly to other campus $\mathrm{Y}$ associations; serving a utilitarian purpose, the handbooks proved to be an effective introduction and link to new students due to the type and nature of the information they provided. Wanting to transfer from Upper Iowa University, John Mott reminisced later in life about receiving a Cornell University student handbook in 1885: "When I had written from the West asking for a university catalogue, the [YMCA] sent me a handbook of information, issued annually by the Christian Association, which it published for the benefit of the students." ${ }^{24}$ By the end of the 1890 s, few campuses were without a student handbook and all served as the student handbook for the institution. Almost every campus YMCA published its own pocket-sized, leather-bound student handbook detailing its institution. In order to subvent the cost and distribute them free of charge to incoming students, $\mathrm{Y}$ men scoured their towns to secure ads from local businesses and then appealed to the students to shop at their patrons' stores. Not until the 1920s would any of the student handbooks be authored by other agencies, either student government groups or the institution itself and even then, non-Y handbooks were few. ${ }^{25}$

Although institutions informed their students of the degree requirements and curriculum in their official catalogues, life outside of the classroom was not elaborated beyond naming the literary societies and perhaps providing lists of the latest graduates and current students. Thus, from the beginning, the Y handbooks were written specifically to orient the incoming freshmen, although upper-class students 
benefitted from the information also. The eight-page 1883 Otterbein University Students' Hand-Book explained that:

This book has been prepared especially to assist students, new and old, in their college work, and to suggest important points for consideration in their college life. ...Every item of this little handbook has been prepared with a view to one of these features of college life, and the time given to its perusal will not be thrown away. ${ }^{26}$

In less than a decade, the YMCA handbooks expanded to 40, then to 60, and to over 100 pages and detailed three general categories of information: logistics, student activities and organizations, and student culture. Logistically, the handbook provided new students with basic information about how to get to the college and what to do when they arrived. The earliest handbooks alerted students to train schedules, as well as post office hours and occasionally neighborhood fire siren codes. ${ }^{27}$ Students were instructed on the process of matriculating and provided a college directory locating administrative and professorial recitation rooms and eventually offices; descriptions of college buildings also appeared as campuses expanded.

As the number of students increased in the 1890s, student activities proliferated, which was reflected in thicker and more detailed handbooks. By the turn of the century handbooks often included a history of the institution, a list of local landmarks, the names and eventually photographs of the academic (and then men's and women's) deans, and memo and schedule pages in the back for students to make notes. Many of our handbooks detail the owner's schedule for at least the fall term, note appointments and social dates, or contain the odd budget. As early as 1889 , one notable and handy feature, the fold-out detailed campus map, often located just the inside back cover of the handbook, found its way into handbooks. Accompanying the description of the buildings, the maps permitted new students to find essential buildings. At some institutions, prospective students receiving the handbooks during the summer could contact current students for information as some handbooks, such as Indiana University's Red Book, 1911-1912, supplied a directory of returning students with their home addresses. ${ }^{28}$

Not surprisingly, in detailing student activities and organizations, the handbooks prominently highlighted the campus community services and activities of the YMCA and if present, but often to a lesser degree, the YWCA. Prior to the 1880 s, the Y associations sponsored primarily prayer meetings and Bible Study courses, but as they became more complex organizations, their services and activities multiplied. New students were thus apprised - and urged to support - the mission and committee work of the $\mathrm{Y}$ associations. Through the 1890s, non-Y campus activities, such as literary clubs, publications, and honor and social fraternities, flourished and assumed more detail and handbook space. Athletics increasingly played a prominent role in the handbooks; competition schedules and campus contests, and in time, conference sports records were noted with pride and were accompanied by cheers and songs, including the alma mater. 
Finally, whether they were published at small private colleges or large state universities, or provided to students in the mid-west or the south, the Y student handbooks explained campus social life and expectations to the newcomers. Containing local campus norms set within universal content sections, the handbooks demonstrate that the campus associations were simultaneously independent and intercollegiate. At summer conferences, state college-Y conventions, presidential gatherings, and state training sessions, leader-representatives of the campus Ys no doubt shared the content of their handbooks with each other. ${ }^{29}$ Two different sections imparted key information for proper freshman behavior. In a section generally called Freshman Rules, the informal, student-imposed social rules of campus life served three purposes: they branded the newcomers, intensified their institutional class membership, and reinforced campus etiquette. Across the colleges and universities, the rules noted places where freshmen were not allowed to sit and what buildings were out-of-bounds, clothing that was not permitted, and people who were off-limits (often the opposite sex). ${ }^{30}$

The similarities among these prohibitions across campuses are remarkable; firstyear students were often not permitted to wear school colors or certain types of clothing or carry specific items. A 1910 Williams freshman was not permitted to wear corduroy or moleskin trousers, purple in any form, or high school insignia; further, he was not allowed to carry a cane, or "spin tops in front of Eddie's." ${ }^{31}$ In general, firstyear men were expected to don their special first-year caps (skull caps, pots, toques, or spots) (except on Sundays and holidays) and to touch the brim when seeing a faculty member or to remove it entirely for the institution's president. As late as 1924, the freshmen at the University of Virginia were instructed "to raise [their] hats to professors [as] evidence of respect and a time-honored custom at Virginia." 32 These rules generally continued in effect until a freshman-sophomore contest of strength or wit, which began to appear at the turn of the century. ${ }^{33}$ Rope pulls, push balls, class rushes, and baseball games were popular, but some colleges devised elaborate contests of sophomores hiding and protection prized possessions that only when found were the first-year students released from the rules. But the cultural guidance offered in the handbooks also extended beyond merely relating traditional Freshmen Rules.

The second section imparted advice to the new students to help in their transition from secondary school to college. At first this section, written in prose, was entitled A Word to the New Student (or New Men), but eventually were presented as a list of Pointers or Useful Hints for New Students. No doubt reflecting on their own struggles to adapt to college life, $\mathrm{Y}$ writers through the years encouraged new matriculates to engage actively in all parts of the collegiate experience: classmates, faculty, athletics, organizations, and of course, academics. The importance of managing time, attending class, seeking information, managing money are themes spread through the handbooks and years. The handbooks also instructed first-year students to practice civility and to avoid self-promotion and frivolous behavior. At Washington and Jefferson (PA), the Y men suggested to the new students in 1901: "Don't be continually telling people what you are. Let them see it from your life and work." The YMCA at Berkeley warned the 1910 first-years: "Only one man in nine ever changes his habits after leaving college. Think about it." And the incoming classes at Newberry 
College (SC) in 1916 and at Roanoke College (VA) a year later were told not to "... get wild and spend (waste) all your money; remember that your mother and father are sacrificing for you." 34

Thus, the handbooks presented new students with logistics, a peek at campus life prior to their arrival, behavior expectations associated with their new (low) social standing, and sage advice for managing their first months. Regardless of how much information initiates were provided beforehand, they arrived as strangers in a strange land. ${ }^{35}$ In a striking shift, the handbooks by the first decade of the new century featured messages by college presidents and various deans welcoming the first-year students and often imparting overt or subtle endorsements of the work of the Associations. Rather than detailing the matriculation directions step-by-step as previous handbooks had, the 1910 Cornell Students' Handbook reminds freshmen to pay attention to the dean's letter of instruction. ${ }^{36}$ By 1924 , the Dean of the University at Virginia penned four and a half pages describing the elements of a successful student. John Morris Page's advice included many of the same issues that the $\mathrm{Y}$ had been covering: rooming guidance, time schedules vs. procrastination, money management, and temptation avoidance. ${ }^{37}$ As administrators started to exercise more interest and direction over student life starting benevolently in the early teens and gradually assuming more control through the 1930s, what constituted important campus information gave way and gradually moved from student opinions to detailed institutional policies and institutional codes of conduct.

\section{The Fall Campaign: Getting Students Settled}

By the late 1880s, the young men of the campus YMCAs had developed several proactive tactics designed to meet the immediate physical and social needs of the new students and of course, to solicit members in the process. The young Y leaders shared their knowledge liberally, representing their campus programs at college $\mathrm{Y}$ meetings at the state level and at the regional Y summer camps and submitting articles to The Intercollegian to disseminate their socialization tactics to other campus associations. However, it took a young man who had appreciated the open hand when he arrived at college to organize and promote these tactics as a strategic plan. John R. Mott, following his graduation from Cornell in 1889, was hired by the national office of the YMCA as the first permanent College Secretary. Mott gathered together the services developed by individual campus Ys, christening the strategy as the Fall Campaign. ${ }^{38}$

The Fall Campaign was calculated and thorough, but the diversity of its elements had been developed well before Mott publicized it as such. Handbooks of course had to be compiled, published, and distributed to incoming students during the summer - tasks that were started during the spring term. Another tactic in the Fall Campaign, which Mott himself experienced at Cornell and was widespread by the end of the 1890s, was to greet and help to settle the incoming students. Train Committee members, sporting ribbons or badges of school colors, met students at the station and conveyed new students and their trunks to campus. Conveyance often meant that the first rooms that freshmen entered on their new campuses belonged to the YMCA.

Between 1879 and the late 1920s, at least 50 campus YMCAs had constructed 
or less frequently acquired their own substantial buildings on campus after conducting self-initiated capital campaigns. ${ }^{39}$ On other campuses, such as Washington and Jefferson College, The College of William and Mary, and Worcester Polytechnic Institute, administrators provided dedicated rooms to the campus YMCA to conduct their religious and social activities. ${ }^{40} \mathrm{New}$ students visiting the $\mathrm{Y}$ rooms or building for the first time found information, housing, and employment bureaus, administered and managed by the association's committees. Freshmen could receive matriculation instructions from the Information Bureau as securing admission to the institution for some and course registration for all was crucial. Locating housing was also an immediate concern for most men. Since most colleges and universities lacked dormitories, new students could consult lists of approved lodging in local rooming houses. The 1886 Students' Handbook published by the University of Virginia Y provided a list of licensed boarding houses "situated outside the University grounds" as well as University Boarding Houses and University Mess Clubs. Again, this service diffused to other associations quite quickly. The Olivet College Y maintained a list of boarding houses in anticipation of new student needs as early as 1888. Many institutions at the time had no student dining accommodations. Thus, the Purdue University Hand-Book explained how to find an eating club, advising that "an underfed student is generally an inefficient student." Information about room and board continued to be offered by the Y's bureau at some institutions, primarily the large state institutions such as Indiana University, through the 1930 s. $^{41}$

Well before institutionalized financial aid offices, freshmen often needed assistance to pay their expenses and most YMCAs operated Employment Bureaus to connect jobs with workers. The earliest notation of an Employment Committee within the YMCA committee structure appears in the 1896 Vanderbilt handbook. Three years later, the University of Michigan YMCA bragged of "helping a large number of students in finding employment... and asking for nothing but [their] gratitude and friendship" during the previous year. In 1903, students at Brown University could be engaged in "table waiting, caring for lawns and for furnaces, clerking, tutoring, collecting, typewriting, etc." In 1915, the Olivet Christian Associations both "maintain committees which co-operate with faculty and townspeople in finding work" for the $75 \%$ of students who earned part of all of their expenses for college. In the 1917 Colorado Agriculture College Handbook, the Y boasted that "last year approximately $\$ 5,000.00$ worth of employment was handled through the office." Although the University of Michigan had shifted the responsibility for student employment to the Dean of Students by 1921, employment bureaus continued to be operated by the $\mathrm{Y}$ on most campuses through the $1920 \mathrm{~s}$ and even into the 1930s. ${ }^{42}$

The creation of one of the primary events of the Fall Campaign preceded John Mott's student experience at Cornell by a decade and continued on almost every campus with a YMCA well into the 1930s. Regardless of what other freshmen activities the campus Ys sponsored, the Freshman Reception was ubiquitous. In October, 1878, the campus YMCA at East Tennessee University (now the University of Tennessee) sponsored the first reception for new students. With a welcome banner stretched across the hallway, the $\mathrm{Y}$ members received the new students in evergreen-decorated 
meeting rooms. New students gazed upon biblical pictures and "spatter work" religious mottoes. Freshmen sang "What a Friend We Have in Jesus" accompanied by a cadet at the organ, prayed, sang again, listened to Scriptures, were welcomed by the Y president and by one of the professors, and finally were rewarded with refreshments, provided by townswomen. ${ }^{43}$

Indeed, the purpose of this first reception and those held by almost every campus association from the 1880s through the first decade of the new century was foremost religious and association-oriented. At Dickinson in 1909, the program for the reception, held the first Friday of the fall semester, followed much the same pioneering religious agenda from Tennessee. ${ }^{44} \mathrm{Y}$ members of course sought to extend their membership and influence among the new students and were supported by the college personnel in these efforts. Yet by the second decade of the $20^{\text {th }}$ century, the receptions began to shift in content and emphasis.

From the earliest days, associations invited faculty and administrators to participate in the receptions; at first, the professors who attended were members themselves. But as the receptions became institutionalized, the social event prompted additional ends. Freshmen were often warned not to miss the reception as it became the opportunity for the new students to become acquainted with administrators and faculty and also with the leaders of the campus association. By 1910, the YMCA receptions featured campus leaders at Williams and Dartmouth, who provided overviews of the various student activities that new students could join. ${ }^{45}$

By the late 1920s, the receptions seem either to have dwindled in popularity or may have become too expensive for the Associations to sponsor alone on larger campuses. Instead, some campus YM and YWCAs jointly hosted "mixers" during the first days of the fall term, a decidedly secular activity. On the campuses with the stronger $\mathrm{Y}$ associations, receptions continued well into the late 1930s, but often were incorporated into the institution's orientation program. At Harvard's religious associations' Phillips Brooks House, the 1939 Y members sponsored films orienting students to the campus on one evening and speeches and songs the next. During the last days of the 1930s, the Penn State and Clemson YMCAs held evening events featuring spoofs about administrators and stunt nights. Weiner roasts, corn roasts, picnics, and suppers became added inducements to attract freshmen to the $\mathrm{Y}$ receptions by the midto late-1930s. ${ }^{46}$ Thus, the receptions - not to mention the handbooks - confirmed the continued leadership of the $\mathrm{Y}$ associations even as numerous campus groups began to vie for the attention of the newcomers. The receptions also permitted the $Y$ associations to herald the social side of their program.

\section{Continuing Methods of Socialization}

As the $\mathrm{Y}$ associations advanced their role on campus, they initiated new activities aimed specifically at freshmen. The YMCA president of Northwestern University noted in his annual report of 1894-1895 that:

The most critical day in a young man's life is the day on which he leaves home for the first time to enter upon a college career. To aid in practical ways young 
men to whom the college surroundings are new and strange, to make the beginnings of the college life pleasant, and above all to help them in the formation of safe friendships, is a part of the mission of every College Christian Association. ${ }^{47}$

This mission continued through the decades. The Massachusetts Agricultural College (MAC, now University of Massachusetts, Amherst) Freshman Handbook, 1925-1926 stated that "The first duty of the [MAC Christian Association] is to welcome the freshmen, to help him get settled and become acquainted with college life." The campus associations continued to receive suggestions from the national YMCA through manuals subsequent to Mott's early pamphlets. ${ }^{48}$

Many of the campus associations - for example, at Northwestern (1892), Penn College (1892), Ohio Normal (1894), and Cumberland University (1896) - apportioned responsibility to a standing committee entitled Freshman Work or New Student Committee well before the National YMCA officer, Gale Seaman published his 1921 pamphlet. ${ }^{49}$ However, after the mid-1920s, many of the associations, such as Penn State (1925), Nebraska (1926), Kentucky (1927), Michigan, (1928), Susquehanna (1930), and Bucknell (1931), appear to have shifted the onus of leadership from the upper-class Y men to the freshman themselves, fostering Freshman Councils, Cabinets, or Clubs. ${ }^{50}$ These groups, such as the Freshman Friendship Club at the University of Florida or the George Williams Club at the University of Minnesota, enabled freshmen to address their unique first-year problems through discussions and lectures and of course, also to contribute to Y work. ${ }^{51}$ As late as 1941, Vanderbilt upper-class Student Christian Association members served as leaders of Freshman Group Discussions held between late November and early December. They facilitated the first-year students in probing such student development issues as "How to strike my balance between classes and activities", "With whom shall I make friends and what for?", and "How to be myself in college (in the midst of conventions). ${ }^{52}$

\section{Freshman Camp}

In addition to these secular year-long activities, campus YMCAs across the nation operated a specialized orientation program beginning in the mid-1920s — the Freshman Camp. Held just prior to the beginning of the fall term, the campus YMCA Freshman Camps focused on cultivating freshmen talent, for the campus as well as the Y. The first Freshman Camps coincided with some of the earliest administratively-sponsored freshmen orientation programs. On some campuses, the camps served as the institution's freshman orientation; elsewhere they supplemented the official institutional program.

The first camp apparently was initiated by the YMCA at the University of Illinois in 1926, although the same year, the Universities of Minnesota Y involved freshmen in a pre-term retreat for student leaders. Immediately successful, the University of Minnesota YMCA Freshman Camp was known as "a place where friends, not speeches would be made" and continued under Association control until the institution took 
over in 1954. Within three years of the first outings, Freshman Camps were held at such geographically diverse institutions as Nebraska, Vanderbilt, and MIT. The programs became increasingly popular with each year; the MIT camp attracted 88 students during its first year, but by the third year accepted only 160 applicants in order of application receipt. ${ }^{53}$

At the 1929 Blue Ridge YMCA/YWCA Summer Conference, Y representatives from 13 southern campuses received instruction on organizational methods as well as potential "Frosh Week" (Freshman Camp) activities: find a suitable location off campus; provide lectures on making the most of college and information on religious education and employment; schedule recreation time with upper class men; and develop leaders from the orientation experience. ${ }^{54}$ By 1932, the camps - taking first-year students off-campus to a rural campsite to train leaders, build camaraderie, and recruit association members - had spread to institutions such as Ohio State, Miami University, Cornell, Brown, and Colgate. As the idea of Freshman Camp diffused, the programs and their length varied from a weekend to a full-week of activities. Some Freshman Camps lasted for decades. In 1962, the Texas A\&M Y held its two-day Freshman Camp over the two days prior to "Fish Week" (New Student Program), limiting its participants to 200. Like their predecessors, new male students participated in group discussions, worship, and group sports. ${ }^{55}$

\section{Conclusion}

The services offered to new students by the campus YMCAs all over the country specifically addressed the immediate needs of information, employment, housing, and friendship. The young men devised these services on their own, tackling areas of student need that the institutions either ignored or neglected. ${ }^{56}$ Presidents, deans, and faculty members welcomed the involvement of the YMCA not only to fill in the gaps resulting from limited professional personnel, but because the mission of the associations was wholesome. ${ }^{57}$ However, the domination of orientation by the $\mathrm{Y}$ associations was doomed to change with the organizational transformations that collegiate administrators and non-Y students initiated through the 1920s and 1930s.

The enrollment surge of the 1920s required campus leaders to rethink the organizational methods of operation on almost every campus. Freshman Week began at Maine in 1923 with an eye toward easing the transition of a diverse and somewhat unprepared first-year class. ${ }^{58}$ As the formula was adopted and adapted by other institutions throughout the country within the next few years, the $Y$ programs became superfluous. By the early 1930s, presidents of various large state universities began to alter the organizational structure of their institutions into specialized bureaucracies with the intention of streamlining the operations and offering more dedicated services. ${ }^{59}$ As dormitories were built, the Ys' housing bureaus were no longer needed. When the Great Depression lingered and the federal government established the National Youth Administration, campus offices dedicated to distributing financial aid emerged, replacing the Y Employment Bureaus. ${ }^{60}$

During the teens, the number of student activities proliferated and faculty started 
to exert control over students' non-academic pursuits. Several Y handbooks published rules for participation in institutional-sanctioned student activities consisting of either a numerical formulae devised by faculty to limit the number of activities and offices in which students could participate or general rules of eligibility. ${ }^{61}$ As the student body diversified, secular student governing boards assumed responsibilities for overseeing the multitude of activities, replacing the decades-long Y domination. ${ }^{62}$ And of course as enrollments grew, the annual Y fall receptions became unwieldy. ${ }^{63}$ Although administrators or student government officers adopted the editorship of some student handbooks, the Y continued to publish this contribution to student life at many institutions well into the 1940s and even 1950s. However, gradually the official institutional regulations and student activities grew too complicated (and eventually legalistic) for the handbooks to be maintained by the Y.

Generations of academics, administrators, faculty, and students often have short memories. What they experience during their tenure in academe is often assumed to have always been - or at least not questioned. Until recently, the accepted accounts of the control over student life have been satisfied with a jump from tight antebellum faculty control to the emergence of the student personnel movement in the 1920 s and especially in the 1930s. Recent historical work has elaborated the administrative evolution, but the role of students in organizing themselves is limited. The scholarship on the evolution of athletics exposes the shift from student initiatives gone awry to management by administrators. ${ }^{64}$ This story of the development of the YMCAs orientation programs highlights only a small part of the role played by this studentled movement on campuses across the country, but it credits the significant, positive, and lasting contributions that a multitude of generations of young men provided to incoming classes of students, long before the professional positions now so normal became so.

\section{Notes}

1 Clarence Cook Little, "President Little Indicates Policies," The Michigan Daily, 36, November 3, 1925), 1. Courtesy of Special Collections Dept., Raymond H. Fogler Library, University of Maine [FLSC-UME].

2 Dellinger reports that 29 colleges and universities across the country had adopted a form of Freshman Week by 1924 and 175 by 1930. M. L. Dellinger, "Freshman Week in the American College", Master of Arts thesis (Charlottesville, VA: University of Virginia, 1931). At the end of the 1920s, 39 of the land-grant colleges were operating a Freshman Week. Arthur J. Klein, Survey of Land-Grant Colleges and Universities, Bureau of Education Bulletin, No. 9 (Washington, DC: GPO, 1930).

3 Clarence Cook Little, Papers about presidency, n.d., 5. Clarence C. Little Papers. [FLSC-UME]. Maine was not the only institution facing ill-prepared students. See a vivid 1928 description of student academic problems at Purdue University as described by its president: Edward C. Elliott, "Educational Experiments and Publicity" Problems of College Education: Studies in Administration, Student Personnel, Curriculum, and Instruction, ed. Earl Hudelson (Minneapolis: The University of Minnesota Press, 1928).

4 Carolyn. T. Bashaw, "Stalwart Women": A Historical Analysis of Deans of Women in the South (New York: Teachers College Press, 1999); Jana Nidiffer, Pioneering Deans of 
Women: More than Wise and Pious Matrons (New York: Teachers College Press, 2000); Kenton Gatyas, "Thomas Arkle and the Office of Dean of Men at the University of Illinois, 1901-1917," Journal of Educational Administration and History 30 (2, 1998): 129 - 145; Robert A. Schwartz, "How Deans of Women became Men," Review of Higher Education 20 (4, 1997): 419-436; Robert A. Schwartz, "The Rise and Demise of Deans of Men," Review of Higher Education 26 (2, 2003): 217-239.

5 Esther Lloyd-Jones, "Personnel Administration," Journal of Higher Education, 5 (1934): 141-147; J. Patrick Biddix and Robert A. Schwartz, "The Legacy of Dr. Walter Dill Scott, Architect of Student Personnel Work," unpublished paper, 2011; Gerald L. Saddlemire and Audrey L. Rentz (Eds.), The Student Personnel Point of View (Washington, DC: American College Personnel Association, 1986), 74-87.

6 Helen Lefkowitz Horowitz, Campus Life: Undergraduate Cultures from the End of the 18th Century to the Present (Chicago: University of Chicago, 1987); Paula S. Fass, The Damned and the Beautiful: American Youth in the 1920s (New York: Oxford University Press, 1979).

7 Smith, Ronald. 1988. Sports and Freedom: The Rise of Big-Time College Athletics. Oxford: Oxford University Press; Thelin, John R. 1994. Games Colleges Play: Scandal and Reform in Intercollegiate Athletics. Baltimore: Johns Hopkins University Press.

8 David O. Levine, The American College and the Culture of Aspiration, 1915-1940 (Ithaca: Cornell University Press, 1986); Harold Wechsler, The Qualified Student: A History of Selective Admissions in America (New York: Wiley, 1977); Marcia G. Synnott, "The Admission and Assimilation of Minority Students at Harvard, Yale, and Princeton, 1900-1970," History of Education Quarterly, 19 (1979): 285-304; Jerome Karabel, The Chosen: The Hidden History of Admission and Exclusion at Harvard, Yale, and Princeton (New York: Houghton-Mifflin, 2005). Rodney M. West, "Student Mortality, Student Survival, and Student Accounting," In Earl Hudelson (Ed.), Problems of College Education: Studies in Administration, Student Personnel, Curriculum, and Instruction (Minneapolis: The University of Minnesota Press, 1928).

9 LeBaron Russell Briggs, Routine and Ideals (Boston: Houghton Mifflin, 1904); F. C. Lockwood, The Freshman and His College (Boston: D.C. Heath, 1913); R. A. Rice, The College and the Future (New York: Scribner's Sons, 1915).

10 John C. French, Review of The Freshman and His College by Francis Cummins Lockwood, College life: Its Conditions and Problems by Maurice Garland Fulton, and The College and the Future by Richard Rice, Jr. Modern Language Notes, 31, (1916): 297.

11 Knode, Orienting the Student, Ernest H. Wilkins, Freshman Week at the University of Chicago, The School Review, 32 (1924): 746-751; Philip L. Harriman, "The Orientation of College Freshmen," Peabody Journal of Education, 3 (1925): 159-161; M. L. Dellinger, "Freshman Week in the American College" (M.A. thesis, University of Virginia, 1931); Charles Franklin Thwing, "New Tendencies Seen in College Education," New York Times (June 8,1924); George W. Rightmire, "The Floundering Freshman," Journal of Higher Education, 1(1930): 185-192; George F. Zook, "The Administration of Student Personnel Work," Journal of Higher Education, 3 (1932): 349-354.

12 George D. Stoddard and Gustaf Freden, "The Status of Freshman Week in Large Universities," School and Society, 24 (1926): 586-589; Lester D. Crow, "Orientation of College Students," Journal of Educational Sociology, 3 (1929): 115-120; William H. Cowley, "Evaluating Freshman Week at Ohio State University," The School Review, 39 (1931): 134-139; E. E. Cordrey, "Freshman Orientation and Guidance in State Teachers Colleges," Peabody Journal of Education, 11 (1933): 138-140; J. Raymond Gerberich, "Freshman Week Program and Testing," School Life, (September, 1936): 9-10, 30; Robert L. Williams, "Present Practice in Offering Guidance to Freshmen in 107 American Colleges and Universities," Peabody Journal of Education, 13 (1936): 
289-296.

13 Jeanine A. Ward-Roof and Cathie Hatch, (eds.) Designing Successful Transitions: A Guide for Orienting Students to College. (Columbia, SC: National Resource Center, 2003); Mary Jo Fabich, "The History of NODA," The Journal of College Orientation and Transition, 15 (2007): 7-9.

14 Julie A. Reuben, The Making of the Modern University: Intellectual Transformation and the Marginalization of Morality (Chicago: Chicago University Press, 1996).

15 Thomas D. Snyder, 120 Years of American Education: A Statistical Report. National Center for Educational Statistics (Washington, DC: GPO, 1993); E. S. Drone, "The New Harvard," Appleton's Journal of Literature, Science and Art, (June 27, 1874): 807; Cornell University, Official Publications of Cornell University, vol. 14, 1922-1923 (Ithaca, New York: Cornell University Digital Archives, http://dlxs2.library.cornell. $\mathrm{edu} /$ )

16 W. H. Hurt, The College Blue Book: Colleges of Liberal Arts and Sciences, vol. 1 (Chicago: The College Blue Book, 1923).

17 Arthur. J. Klein, Survey of Land-grant Colleges and Universities. Office of Education, Bulletin, no. 9 (Washington, DC: GPO, 1930); William H. Cowley, "The History of Student Residential Housing," School and Society, 40 (1934): 705-712; Lulu Holmes, $A$ History of the Position of Dean of Women in a Selected Group of Co-educational Colleges and Universities in the United States (New York: Teachers College, Columbia University, 1939).

18 David P. Setran, The College "Y": Student Religion in the Era of Secularization (New York: Palgrave MacMillan, 2007); Dorothy E. Finnegan and Nathan F. Alleman, "Without Adult Supervision: Campus YMCAs," a paper presented at the annual Association for the Study of Higher Education, 2005.

19 The College Bulletin was initiated by Luther Wishard in 1878 immediately after the International Committee of the YMCA recognized the campus movement as an official part of the organization and named Wishard as a part-time secretary to organize the campuses. The College Bulletin became The Intercollegian in 1898.

20 By 1920, regional summer YMCA conferences were held at Northfield, MA, Silver Bay, NY, Forest Park, PA, Blue Ridge (for white students), and at Kings Mountain (opening in 1912 for African American students), both in NC, Waveland, MS (opening in 1919 for African American students), Lake Geneva, WI, Estes Park, CO, Pacific Grove, CA, and Gearhart Park, WA.

21 YMCA of University of Michigan, Students' Hand-Book of the University of Michigan, 1899-1900 (Ann Arbor: YMCA of University of Michigan, 1899); Shedd, Origin and Development; C. Howard Hopkins, History of the Y.M.C.A. in North America (New York: Association Press, 1951); Snyder, 120 Years.

22 Although the YWCA also gradually became involved in many of these services, the campus YMCA created and should be credited with these innovative services. By the turn of the $20^{\text {th }}$ century, the YWCA often at co-educational co-published and at women's colleges or published alone the handbooks, but they did not initiate the orientation services or programs described here. Thus, we are limiting this discussion to the campus YMCAs.

23 Gradually, after the associations lost their hold on their orientation programs beginning in the mid- to late-1920s at some institutions, the campus Ys initiated a variety of other annual programs during the academic year for first-year students. Freshman clubs, discussion groups that explored life issues such as dating and marriage and social issues, such as race relations, were prevalent on many campuses. This discussion, however, is limited to the YMCAs freshman orientation programs.

24 Hopkins, History of the YMCA, 284.

25 Between 1883 and 1919, our sample includes 75 handbooks, 31 from public 
institutions and 44 from privates. All were published by the local campus YMCA or in a joint effort with the campus YWCA. The sample includes 134 handbooks from the 1920-1949 period. Between 1920 and 1929, only four handbooks were not solely published by the $\mathrm{Y}$ : one was co-authored by the $\mathrm{Y}$ and the student government; two only by the institution, and one by another student group. Between 1930 and 1949, 55 of the 85 handbooks were authored by a campus Y or joint YM\&YWCA (equally distributed between public and private institutions) and only 11 were published by the institution itself - the others arose from student government or other student groups. Thus, between 1883 and $1949,83 \%$ of the 209 student handbooks in our sample were published by the local campus YMCA or co-published with the local campus YWCA.

26 Otterbein University Christian Associations, Students' Hand-Book, 1883-84 (Westerville, OH: Otterbein University Christian Associations, 1883). Courtesy of the Otterbein University Archives.

27 The Students' Christian Associations, Students' Directory (Evanston, IL: The Students' Christian Association of Northwestern University, 1883. Courtesy of the University Archives, Northwestern University [UA-NU]; Y.M.C.A and Y.W.C.A. of Hillsdale College, Student's Handbook, 1885 (Hillsdale, MI: Y.M.C.A and Y.W.C.A. of Hillsdale College). Courtesy of the Hillsdale College Archives.

28 Indiana University YMCA, The Red Book, 1937-1938 (Bloomington, IN: Indiana University Young Men's Christian Association, 1937).

29 Whereas campus association representatives met at first only during the International Convention of the YMCA, by 1884, Luther Wishard reported state or regional conventions for the campus associations occurring in New England, Michigan, Ohio. Luther Wishard, The College Bulletin, VII (December, 1884), 2. And in Indiana after the turn of the century, "About April first, each year, a state conference for the newlyelected leaders of Association work is held at one of the colleges." YMCA of Purdue University, Purdue University Hand-Book, 1910-1911 (Lafayette: YMCA of Purdue University, 1910), 17. The sharing of the rules, prohibitions, and customs is obvious across the handbooks and across the years so much so that we found, in 1927, the Kentucky handbook's Points for Freshmen replicated word-for-word most sub-sections of the 1925 Penn State advice to first years. YMCA and YWCA, University of Kentucky Student Handbook, 1927-28 (Lexington: University of Kentucky YMCA and YWCA, 1927); Pennsylvania State YMCA, The Student Handbook of Pennsylvania State College (State College: Pennsylvania State YMCA, 1925).

30 Based on the content of the handbooks, exclusionary customs were without question aimed at the men and did not include women.

31 Williams Christian Association, Handbook of Williams College, 1910-1911 (Williamstown, MA: Williams Christian Association, 1910), 10; Yale freshman were advised not to partake in spinning tops as the activity was reserved for the seniors. Yale University Christian Association, Yale Students' Hand Book, 1913-1914 (New Haven: Yale University Christian Association, 1913), 8. And in 1916 at Syracuse, class caps were required of both freshmen (green) and sophomores (gray) whereas only juniors and seniors were permitted to carry canes and wear top hats. The Christian Associations, The Student's Hand Book, 1916-1917 (Syracuse: The Christian Associations, 1916), 64.

32 Boy's Work Committee of the UVA YMCA, Handbook of the University of Virginia, 1924-1925 (Charlottesville, VA: UVA YMCA, 1924), 47.

33 At Wooster, the unidentified owner of the 1914 handbook noted in her diary entry of 21 September, that "a few ribs were damaged" in the Freshman-Sophomore Scrap. The Christian Associations, Students' Hand-Book of the College of Wooster, 1914-1915 (Wooster, OH: The Christian Associations, 1914), 82.

34 Washington \& Jefferson YMCA, Student's Handbook of Washington and Jefferson College, 1901-1902 (Washington, PA: Washington and Jefferson Young Men's Christian 
Association, 1901), 5. Courtesy of the Archives and Special Collections Library, Washington and Jefferson College (W\&JC-ASCL); University of California YMCA, Student's Handbook, 1910-1911 (Berkeley, CA: Young Men's Christian Association, 1910), 12; Newberry College YMCA, Student's Handbook of Newberry College, 19161917 (Newberry, SC: Young Men's Christian Association, 1916), 14. The Young Men’s Christian Association of Roanoke College, Student's Hand-Book, 1917-1918 (Salem, VA: Young Men's Christian Association of Roanoke College, 1917), 22.

35 See Nathan F. Alleman and Dorothy E. Finnegan, "Believe you have a mission in life and steadily pursue it': Campus YMCAs presage student development theory, 18941930," Higher Education in Review, 6 (2009): 1-33.

36 Cornell University Christian Association, Students' Handbook, 1910-1911 (Ithaca, NY: Cornell University Christian Association, 1910).

37 Boys Work Committee of the YMCA, Handbook of the University of Virginia, 19241925 (Charlottesville: Boys Work Committee of the YMCA), 61-65.

38 John R. Mott, The Fall Campaign or How to Reach New Students. College Series no. 305 (New York: International Committee of the Young Men's Christian Association, 1891).

39 As the campus Y president, John Mott orchestrated the capital campaign for the Cornell Y building (Barnes Hall) in 1887-1889. The association secured $82 \%(\$ 45,000)$ of the cost of the building through a donation from publisher, Alfred Smith Barnes of New York City. John R. Mott, College Young Men's Christian Association Buildings. College Series \#302 (New York: International Committee of the YMCA, 1891). The one exception to the capital campaigns that we have found to date is the Hampton University YMCA building, Clarke Hall. There the students themselves built the entire building - the outside construction and the fine detail inside. Hampton Institute YMCA, Hampton Students' Hand-Book 1916-1917 (Hampton, VA: Hampton Institute Press, 1916). Courtesy of the Hampton University Archives.

40 Washington \& Jefferson YMCA, (1889). "To The New Students," Annual for 1889. Courtesy of (W\&JC-ASCL); College of William and Mary Y.M.C.A., Y.M.C.A. Handbook (Williamsburg, VA: College of William and Mary Y.M.C.A., 1909). Courtesy of Special Collections, Swem Library, The College of William and Mary; "The History of the Tech Y.M.C.A." Tech News, The YMCA Number. (Worcester, MA: Worcester Polytechnic Institute, April 28, 1913). Courtesy of the WPI Archives \& Special Collections, George C. Gordon Library.

41 University of Virginia YMCA, Students' Hand-Book, 1886-87. (Charlottesville, VA: University of Virginia YMCA, 1886), 10-11. Courtesy of Special Collections, University of Virginia; Olivet College YMCA and YWCA, Information for Students, 1888 (Olivet, MI: Olivet College YMCA and YWCA, 1888). Courtesy of the Olivet College Library Archives; Purdue University Young Men's and Young Women's Christian Association, Purdue University Hand-Book, 1913-1914 (Lafayette, IN: Purdue University Young Men's and Young Women's Christian Association, 1913), 15; Indiana University YMCA, The Red Book, 154.

42 Vanderbilt University YMCA, The Student's Handbook, 1896-1897 (Nashville, TN: Vanderbilt University YMCA, 1896). Courtesy of the Vanderbilt University Archives, Nashville, TN; University of Michigan YMCA, "Employment and information bureau," Students Hand-Book of the University of Michigan (Ann Arbor, MI: The University of Michigan YMCA, 1899), 6; Brown University YMCA, "Employment Bureau," A Hand-Book of Brown University, 1903-1904. Souvenir Building Edition (Providence, RI: University Hall, 1903), 15; Christian Associations of Olivet College, The Student's Hand Book, 1915-1916 (Olivet, MI: The Christian Associations of Olivet College, 1915), 9; Colorado Agriculture College Christian Associations, The Hand Book of the Colorado Agriculture College, 1917-1918 (Fort Collins, CO: Colorado Agriculture College Christian Associations, 1917), 12; University of Michigan 
YMCA, The Michigan Handbook, 1921-22 (Ann Arbor, MI: University of Michigan YMCA, 1921), 48.

43 David B. Johnson, "College Reception," The Watchman, 4 (\#14, 1878): 9.

44 Dickinson College Christian Associations, The Dickinson Handbook, 1909-1910 (Carlisle, PA: Dickinson College Christian Associations, 1909).

45 Williams College Christian Association, 1910; Dartmouth Christian Association; Handbook of Dartmouth College, 1910-1911 (Hanover, NH: Dartmouth Christian Association, 1910).

46 Denison University YMCA \& YWCA, The Handbook of Denison University, 19261927 (Granville, OH: Denison University YMCA \& YWCA, 1926); Ohio Northern University YMCA, The " $Y$ " Handbook, 1927-1928 (Ada, OH: Ohio Northern University YMCA, 1927); Harvard University Phillips Brooks House Association, The 50th Harvard Handbook, 1939-1940 (Cambridge, MA: Phillips Brooks House Association, 1939); Penn State Christian Association, The Student Handbook, 19381939 (University Park, PA: Penn State Christian Association, 1938).

47 Clayton D. Lee, (Annual Report of the President of the Young Men's Christian Association, College of Liberal Arts, Northwestern University, 1894-5 (Evanston, IL: Young Men's Christian Association, 1895), 4. (UA-NU).

48 Massachusetts Agricultural College Christian Association, The Freshman Handbook of Massachusetts Agricultural College, 1925-1926 (Amherst, MA: Massachusetts Agricultural College Christian Association, 1925), 10; see David R. Porter, The Necessity of the Student Christian Movement (New York: National Council of the Y.M.C.A., 1927).

49 The Christian Associations, Students' Hand Book, 1892-93 (Evanston, IL: Northwestern University Christian Associations. (UA-NU); Y.M. and Y.W.C.A., A Hand Book for Students, 1892-1893 (Oskaloosa, IA: Y.M. and Y.W.C.A of Penn College, 1892). Courtesy of the Wilcox Library Archives [WPU-WL], William Penn University; Young Men's and Young Women's Christian Associations, Students' Hand Book, 1894-5 (Ada, OH: Young Men's and Young Women's Christian Associations of Ohio Normal University, 1894); Young Men's Christian Association of Cumberland University, Students' Hand Book, 1896-7 (Lebanon, TN: Young Men's Christian Association of Cumberland University, 1896); Gale Seaman, Work with New Students (NY: Association Press, 1921).

50 YMCA of Penn State, Students' Handbook, 1925-26 (State College, PA: YMCA of Pennsylvania State University, 1925); The University Christian Associations, Students' Hand Book, 1926-27 ( Lincoln, NB: The Christian Associations of the University of Nebraska, 1926); Y.M.C.A. and Y. W.C.A., University of Kentucky Student Handbook, 1927-1928 (Lexington, KY: Y.M.C.A. and Y.W.C.A., 1927); Student Christian Association, The Freshman Handbook, The Official Handbook of the University of Michigan, 1929-1930 (Ann Arbor, MI: Student Christian Association, 1929); Y.M.C.A. and Y.W.C.A., Both sets of examples do not imply an evolutionary pattern. The handbook collection does not include enough institutions to determine more than general trends.

51 As this research focuses on the first-year student orientation services and activities provided by the campus YMCAs, we refrain from discussing the many other activities promulgated by associations through the decades. Beginning in the teens, many of the associations tackled social issues including race in both discussion and action. For example, the $\mathrm{Y}$ at UNC-Chapel Hill established evening classes for African American youth and unemployed men as well as an African American YMCA in 1914. At Minnesota in the late 1920s, a biracial committee from the YM \& YWCAs researched the discriminatory practices that university students faced. As late as 1956, Minnesota's Fair Gopher (the university mascot) Council continued to address discriminatory 
practices against students in the city. Stiles Hall, Berkeley's Y, ensured that Japanese American students, interned during World War II, had reading materials and visitations. See Anthony Wayne James, Defining the Boundaries of Racial Liberalism: The Student YMCA and Interracial Activity at the University of North Carolina, 19101939, a Master of Arts thesis (Raleigh, NC: North Carolina State University, 1992); Richard M. Breaux, "Using the Press to Fight Jim Crow at Two White Midwestern Universities, 1900-1940" in Eileen H. Tamura, ed., The History of Discrimination in U.S. Education (New York: Palgrave MacMillan, 2008); Minneapolis YMCA University Branch, "Fair Gopher Plan" [draft], (Minneapolis: Minneapolis YMCA University Branch, 1956. Courtesy of the Kautz Family YMCA Archives, University of Minnesota [UM-KFYMCAA]; and Frances Linsley, What is This Place? An Informal History of 100 Years of Stiles Hall (Berkeley, CA: Stiles Hall, 1984). Although many campuses were segregated either de jure or de facto, numerous $\mathrm{Y}$ associations led other students in discussing and reflecting on their behaviors toward dissimilar others beginning in the teens. In 1924, resolutions were adopted by representatives from colleges in Colorado, Nebraska, Kansas, and Wyoming supporting the passage of the Dyer Anti-Lynching bill, calling for the repeal of the immigration laws that discriminated against Japan, seeking leaders from especially the African American community to address student meetings to enlighten them "as to the facts in race relations", and expressing their conviction that segregation by race in "housing facilities, in trains, in eating houses, amusement halls, and in other public places is wrong and unjustifiable." "Resolutions Passed at Estes Park Men's Student Conference", June 1-16, 1924. Courtesy of the Howard University Moorland-Spingarn Research Center, Jesse E. Moorland Collection YMCA, Box 126-39, folder 813. Certainly freshmen would have been influenced by these activities on the part of their upper-class $Y$ peers. However, these types of activities were not part of the orientation program for new students, but rather activities and programs for the entire association and the larger campus.

52 Edgar C. McVoy, "Letter to Freshman" (September 2, 1932) Young Men’s Christian Association of the University of Florida. Courtesy of the University of Florida Archives, MS58, Box 2 YMCA Records, 1922-1953, f-1 Camp, Freshman [1932] - 39; Freshman Week Committee, The University of Minnesota Freshman Handbook. (Minneapolis, MN: University of Minnesota YMCA, 1927); Henry G. Hart, "Memo to Leaders, Freshman Group Discussions," (Vanderbilt University YMCA, 1940). Courtesy of Vanderbilt University Archives, RG700, Student Affairs, Box 1319, Student Christian Association, 1941-43.

53 University of Illinois Christian Associations, The University of Illinois Students' Hand Book (Urbana-Champaign, IL: University of Illinois Christian Associations, 1926); YMCA Centennial History Committee, A Timeless Place: The University of Minnesota YMCA, 1887-1987 (Minneapolis: University of Minnesota YMCA, 1987). Local Histories: The University YMCA, 1887-1987 (UM-KFYMCAA); Technology Christian Association of the Massachusetts Institute of Technology, The Handbook, 1929-1930 (Cambridge, MA, Technology Christian Association, 1929).

54 Blue Ridge Conference, "Frosh Week," Frosh Work (1929), 4. Courtesy of the Special Collections Department of Smathers Library, University of Florida. p. 4). The schools listed with Frosh Week programs varying in length from four events to one full week are North Carolina State University, Louisiana State University, Emory University, Roanoke College, Louisiana Polytechnic Institute, Wofford College, University of Tennessee, Mississippi A\&M, Tusculum College, University of South Carolina, Vanderbilt University, University of Virginia, and the University of Miami. 
55 Agricultural and Mechanical College of Texas YMCA, Freshman Handbook 1962-63 (College Station, TX: Agricultural and Mechanical College of Texas YMCA. (1962).

56 Many of the larger campus associations employed graduate students at first and then professional "adult" secretaries to oversee the operations of the group. The first professional secretaries appeared concurrent with the construction of student association buildings, first at Yale and Toronto in 1886-87. A few smaller associations employed professionals for a year or so, but undoubtedly could not sustain the expense and retreated quickly to running their own show. However, the programs were initiated and operated through student-led committees.

57 See Andrew D. White, "Heresy in Colleges" Old and New, January, 1870, 1; Woodrow Wilson, "The Significance of the Student Movement to the Nation," The Intercollegian, 25 (January, 1903), 82-83.

58 Of the 353 students, on the IQ test (otherwise called a psychological test) administered during the second Freshman Week, 22 scored an 80 quotient and 23 scored a 120 or higher quotient. The vast majority of students fell between the 90th and $115^{\text {th }}$ quotient. Results of Psychological Tests on Freshmen of Maine, (September, 1924). Clarence C. Little Papers, MS 300, Box 741, folder 2. [FLSC-UME].

59 Alexander G. Ruthven, "Administration at Michigan: A Plan by Which the Members of the Faculty Will Receive a Larger Measure of Self-government but More Responsibility," The Journal of Higher Education, 2 (Jan. 1931): 7; "The New Council at the Ohio State University," School and Society, 40 (22 Dec. 1934), 836-37.

60 Robert Sutton, "Interview with William Guthrie," (Dec. 7, 1983), The Ohio State University Knowledge Bank, 2, http:hdl.handle.net/1811/1479.

61 The YMCA and YWCA Handbook Committee, "Control of Activities," Students' Hand-Book of Penn College, 1912-1913 (Oskaloosa, IA: The Christian Associations of Penn College), 57-58 (WPU-WL); The Christian Associations of Oberlin College, "Rules and Regulations of Outside Activities", The Oberlin College Handbook, 19141915 (Oberlin, OH; The Christian Associations of Oberlin College), 62-63; Christian Associations of Cornell University, "Rules Governing Student Organizations," Cornell Students' Hand Book, 1911 (Ithaca: Christian Associations of Cornell University), 47-48.

62 See chapter one especially of Allison Hawkins Crume, "The Historical Development of The Student Government Association as a Student Sub-Culture at The Florida State University: 1946-1976" (Ph.D. diss., Florida State University, 2004); B. H. Peterson, "Student Government in Collegiate Institutions," The Journal of Higher Education, 14, (April, 1943), 205-208.

63 At UNC-Chapel Hill, "the Social Committee has changed the annual reception for a pushing, punch-pilling mob at a meant-to-be-very-formal affair in the by-far-too-small Y.M.C.A building to a really home-like delightful reception in the adequate spaces of the library." Philip Woollcott, "Fifty-four Years of the Y.M.C.A." draft manuscript intended for the Carolina Magazine, April 1914, 5. Records of the Campus Y (\#40126). Courtesy of the University Archives, Wilson Library, University of North Carolina at Chapel Hill.

64 Smith, Sports and Freedom, 1988; Thelin, Games Colleges Play, 1994. 